\title{
Police integrity and the perceived effectiveness of policing: Evidence from a survey among Ugandan police officers
}

\author{
Natascha Wagner and Wil Hout
}

\begin{abstract}
Research on police integrity has focused to a large extent on the assessment of the seriousness of various forms of police misconduct. Employing vignettes cases it has been shown that police officers identify clear differences among forms of misconduct and these differences largely hold across countries and contexts. Moreover, the impact of a range of individual and organizational characteristics on the assessment of misbehavior has been established. This chapter analyzes the impact of perceptions of the institutional environment and police effectiveness among Ugandan police officers to assess the external validity of the assessments of the seriousness of misconduct presented in the vignettes. The research focuses on ten aspects of police officers' perceptions of the institutional environment and police effectiveness and shows that the perceptions are strongly interrelated and that they impact on attitudes towards police integrity. Thus, while the vignettes are meant as a tool to reduce subjective biases in the evaluation of police misbehavior, the assessment of the vignettes is not free of individual perceptions. This suggests that the vignettes can be seen as means to channel and represent the individual subjective biases in a coherent and comparable form.
\end{abstract}

Keywords: Police integrity, Uganda police force, perceptions, police misbehavior, vignettes

\section{Introduction}

As a key element of the 'strong arm' of the state, the police have generally been the subject of much academic research. The police face the so-called 'paradox of violence' of the democratic state: the police (next to the army) claim the monopoly on the legitimate use of violence, but also need to respect legal restraints on the actual use of its powers. As argued by Gary Marx (2001), 'a democratic society needs protection both by police and from police'. Given the role of police in society, the integrity of police officers is very important. Moreover, identification of the factors that promote police integrity and those that hinder it has considerable societal relevance.

Research on police integrity has grown substantially over the past two decades (see the overview of publications in Kutnjak Ivković, 2015: 18-30). The academic literature in this field received a major boost with the seminal work of Klockars et al. (2000), who developed a method for the measurement of police integrity built on hypothetical cases (vignettes) rather 
than attempts to ask police officers direct questions about their behavior. The advantage of the approach is that it reduces bias since the vignettes do not directly inquire about own behavior but ask for the assessment of the hypothetical behavior depicted in the cases. Moreover, the vignettes allow the presentation of a set of uniform cases to all study participants independent of their experience and (socio-economic) background. This method was underpinned by the so-called organizational theory of police integrity, consisting of four dimensions: organizational rules, techniques of controlling police misconduct, the police agencies' efforts of curtailing the 'code of silence' in the police force, and the influence of the social and political environment on the police force (Kutnjak Ivković, 2015: 5-11).

Previous studies have mainly focused on the internal validation of the vignette approach to police integrity. First, studies have demonstrated that more severe cases are judged more severely (e.g., Jenks et al., 2014: 330). Second, the vignettes have shown to be applicable across countries and contexts, subject to minor context-specific adjustments, thus yielding coherent results (Kutnjak Ivković and Haberfeld, 2015: 334)

In order to add to the existing body of work evolving to a large extent around the internal consistency of the vignette approach, this chapter aims to assess the external validity of the vignettes. Thus, we link evaluative questions about the vignettes to the perceived institutional environment and perceptions of police effectiveness and assess to what extent they are related. We consider the police officers' own perceptions of the situation and the work of the police as prime candidates for such an analysis.

This chapter uses questions about the perceptions of the institutional environment and police effectiveness among Ugandan police officers to contextualize the findings on police integrity measured by the vignettes. We have identified ten elements of the perceived institutional environment (e.g., similar treatment by age, gender, and socio-economic status; level of crime in the community) and police effectiveness (e.g., confidence in own and colleagues' work) and analyze the relationship of these elements with the evaluative responses to the vignette cases. Our data, collected in 2015 in an attempt to evaluate a police reform project (see, e.g., Hout et al., 2016: 51-75), expressly contained questions about the wider environment of the Ugandan police force, as well as police officers' own assessments of their work situation and perceptions of the operations and effectiveness of the police organization. Thus, our research attempts to contribute to research in the tradition of the organizational approach to police integrity by focusing mainly on how police officers' perceptions of their institutional environment may impact on their position on various forms of police misconduct. 
Next to adding to insights about the external validity of the vignettes, we make a methodological contribution to the literature on police integrity. While it is relevant to assess the hypothetical cases one by one and compare the assessments of police officers, we feel it is equally valuable to pool the outcomes and look at patterns underlying the ensemble of vignettes to contribute to a deeper understanding of the usefulness of vignettes.

\section{Police integrity and perceptions of the police force}

Research in the field of governance has led to the definition of integrity as the quality of acting in accordance with relevant moral values, norms, and rules' (Lasthuizen et al., 2011: 387), where integrity can be a quality both of individuals and organizations. Police integrity is commonly understood as 'the normative inclination among police to resist temptations to abuse the rights and privileges of their occupation' (Klockars et al., 2006: 1).

The literature on police integrity has hitherto focused mostly on the impact of various (socio-economic and experience-related) characteristics of police officers and the infrastructure and overall situation of the police agencies on the perceptions of seriousness of police misconduct and the perceptions of fellow officers' willingness to report (Kutnjak Ivković, 2015: 18-27). Research focusing on perceptions of the institutional environment in the police force has remained surprisingly scarce, although it is not difficult to argue that the way in which police officers perceive their environment may have an impact toward their attitudes on misconduct and their willingness to report acts of misconduct.

Several studies have demonstrated how differences at the macro-societal level impact on police officers' attitudes to corruption, the treatment of prisoners, and other forms of misconduct. For instance, Kutnjak Ivković et al. (2016) report on research among the police in Croatia and show that features of society at large seem to play a role in officers' assessment of police misbehavior, although the impact of such community characteristics is limited by variations in organizational features of the police. Further, a study on police integrity in Russia finds a clear impact of the overall societal perception of corruption. The authors of that study (Cheloukine et al., 2015: 179) conclude as follows:

In the environment in which corruption is entrenched into everyday life and everything is for sale, the acceptance of kickbacks ... and thefts from the crime scene ... are the new 'normal.' In the situation in which planting of evidence on innocent people and falsification of official records to bust the arrest records are occurring on a regular basis, falsification of a police record ... and a failure to exercise an arrest warrant on a friend ... are also 
becoming the new 'normal.'

Comparative studies on police integrity corroborate the impact of the institutional environment and, in particular, of the social perception of corruption (e.g., Andreescu et al., 2012: 198-199; Kutnjak Ivković and Haberfeld, 2015). Further, comparative research on the treatment of suspect behavior and the use of force indicates how the culture of a police force seems to impact on the attitudes of police officers toward the use of force (Waddington et al., 2009: 134-135). Finally, a team of French researchers demonstrated how the 'professional ideologies' of police officers (expressed in the three main positions that police activity should be mainly repressive or preventive or a combination of both) are impacting on their opinions on the role of the police (Coulangeon et al., 2012).

Relatively little research has so far been done on the perceptions of police officers regarding the police force and on how these perceptions affect police officers' attitudes toward misconduct and their willingness to report misconduct. Various studies have addressed the impact of the organizational culture and the code of silence on the perceptions of police officers about police integrity (e.g. Kucukuysal, 2008; Kutnjak Ivković and Sauerman, 2015), while others have analyzed the impact of different disciplinary environments on perceived disciplinary consequences of misconduct (e.g., Lee et al., 2013; Kutnjak Ivković and Khechumyan, 2014; Cheloukine et al., 2015; Kutnjak Ivković et al., 2016; Kuo, 2018). Further, a number of studies have focused on the impact of perceptions of disciplinary fairness (i.e., how fair do officers feel that the disciplinary consequences of their behavior are?) on the likelihood that misconduct will be reported and the code of silence will be broken (e.g. Kutnjak Ivković and O'Connor Shelley, 2010; Long et al., 2013; Kutnjak Ivković and Sauerman, 2013; Porter et al., 2015). Wolfe and Piquero (2011) showed how different aspects of perceived organizational justice - broken down into distributive, procedural and interactional aspects - influence the incidence of police misconduct. Using a slightly different approach, Myhill and Bradford (2013) demonstrated how perceptions of organizational justice impact positively on police attitudes to serving the public. Finally, a study by Bucak (2012) has shown that police cynicism (understood as the pessimistic outlook of police officers towards their job) has an impact, albeit moderately, on police integrity.

The lack of attention to perceptions of police officers on the functioning of the police force, and particularly its effectiveness, has motivated the current study. We feel that a more profound analysis of police officers' perceptions of the effectiveness of their own work and its possible relationship with police integrity would contribute to a better understanding of the 
influence of the social and political environment on the police force (the fourth dimension highlighted in the organizational theory of police integrity). In a similar vein as Bucak (2012: 44-49) we start from the hypothesis that the way in which police officers appreciate their work, and in particular the degree to which they believe that their work contributes to social values, impacts on the way they perform their duties. Thus, the perception of one's own work as being ineffective may lead to the acceptance of corruption and other forms of misconduct on the part of the police.

\section{The Uganda National Police}

Before moving on to our empirical analysis we present some background information about Uganda and its police force. Since 1986, Ugandan politics has been dominated by President Yoweri Museveni's National Resistance Movement (NRM), the political successor to the National Resistance Army (NRA), which prevailed in the Ugandan Bush War, the protracted civil war against the regime of Milton Obote (1980-1985). The Ugandan 'Movement System', which existed from 1986 until 2005, was envisaged to be a non-party political system, where representatives were elected on individual rather than party platforms. Museveni won the first Ugandan presidential elections in 1996 and was re-elected to the presidency in four subsequent national elections (2001, 2006, 2011 and 2016). Although Uganda has had multiparty elections since the mid-2000s, Museveni's regime has become increasingly authoritarian. Regime maintenance became an important objective, and this led to the search for instruments to broaden the regime's support base among the Ugandan population (Khisa, 2014).

Increased opposition led the Museveni regime to mobilize political support for the NRM by using patronage-driven appointments and tolerating corruption, the rising costs of which have been labeled 'inflationary patronage' (Khisa, 2014: 32-36; Barkan, 2011; cf. Tangri and Mwenda, 2013). Decentralization has been an important instrument of patronage; the increase of the number of districts from around 40 in the mid-1990s to 111 since 2012 (Ministry of Trade, Industry and Cooperatives, 2017) served as a means for the regime to appoint its supporters to local government positions (Golooba-Mutebi and Hickey, 2013: 1617). Further, the NRM government became increasingly repressive, targeting independent media, the judiciary and opposition parties (Anderson and Fisher, 2016). In recent decades, the Uganda National Police and the national army have been important instruments of the regime's attempts to maintain power. A former army commander, Major-General Mugisha Muntu, and current opponent of the Museveni regime, characterized the Uganda National 
Police recently as 'an extension of the ruling party' (Economist, 2018).

The Ugandan police force was institutionalized in 1906 (Uganda Police Force, 2007) and has officially been known as 'Uganda National Police' since April 2014 (Lumu, 2014). It is divided functionally into 20 directorates based on tasks and geographically into regional and district offices, police stations and posts (Uganda Police, 2015). Data about the police and policing activities is scant since the statistical capacity of the police is weak (Uganda Police Force, 2007). In the early 2000s, Uganda had fewer than 15,000 police officers, with considerable year-to-year variation according to the available statistics (Commonwealth Human Rights Initiative, 2006a: 26-27). In 2007, the Ugandan police force experienced a major increase of personnel - it went from approximately 27,000 to 48,000 officers - and saw the creation of more directorates in preparation for the Commonwealth Heads of Government Meeting (Xinhua News Agency, 2007). At the end of 2014, the Inspector General announced an increase of the police from roughly 40,000 to 65,000 officers (Kakamwa, 2014).

Concerning crime statistics and the security environment in Uganda, 252,065 crimes were reported in 2017, resulting in a crime rate involving 667 victims per 100,000 Ugandans (Uganda Police, 2017: 2). Public sector crime investigations have been declining over a range of years. The Ugandan police reported 37 cases of corruption in 2017, compared to 194 in 2016 and 413 in 2013 (Uganda Police, 2013: 9; Uganda Police, 2017: 8). Background information on the types of public sector corruption are not provided leaving it open whether corruption within the police is also included in these figures. The 2013 Crime Report indicated 19 cases in which police officers were under investigation of suspected crimes (Uganda Police, 2013).

Uganda is in the top quintile of the most corrupt countries according to the 2018 Corruption Perceptions Index (Transparency International, 2018) and the Ugandan police is regarded as particularly corrupt (Wambua, 2015; Basheka, 2013: 72-74; Transparency International-Kenya, 2013). Results of various surveys - including Uganda's National Service Delivery Study 2015 (Kato, 2016) and older surveys carried out by the Commonwealth Human Rights Initiative (2006b) between 1998 and 2005 - indicate that a majority of Ugandan citizens have consistently rated the police as the most corrupt institution in the country.

The characteristics of corruption and fraud in Uganda, and the perception of corruption within the Ugandan national police, make the country an interesting case to study police integrity in relation to the extent to which police officers themselves perceive their 
work as effective. We expect that, in particular, the high-corruption context of Uganda may reveal challenges to integrity and professionalism among the police.

\section{Survey set up, sampling, and questionnaire}

Our data are derived from interviews with police officers from 10 of the 143 Ugandan police districts (Uganda Police, 2017: e, f). The survey districts are Bushenyi, Iganga, Jinja, Kabale, Kabarole, Tororo, Luwero, Mbarara, Mityana, and Soroti. On purpose, no single Northern Ugandan district was sampled because of the impact of the conflict between the Ugandan government and the Lord's Resistance Army rebels on the region. We employed the vignette cases along with questions about the perception of police work among 600 police officers in the 10 selected districts, sampling 60 officers within each district. The data collection was carried out by our local university partner, the Uganda Management Institute. The research team worked in close collaboration with the police. After authorization from the police headquarters, the local research team wrote a letter to the regional police officers informing them about the activities and asking for support. The research team then identified the study participants together with the police. The district-level sampling strategy was well respected with only some very minor deviations: in two districts only 59 officers could be interviewed, while in another two districts 61 officers were interviewed. Thus, the target sample of a total of 600 individuals was reached since officers that could not participate were replaced.

We organized the survey in groups of 30 officers. Survey activities took place at the local level. To this end we rented venues that where equipped with enough tables and chairs for 30 police officers. To reach the target number of 60 officers per district, at least two survey sessions took place in every district, one in the morning and one in the afternoon of the scheduled survey days.

In an introduction, the enumerators presented the survey to the participating police officers and allowed for questions. The survey was conducted in English since English is one of the two official languages in Uganda and widely spoken in public services and government. The survey consisted of a self-administered pen and paper questionnaire. Each police officer was provided enough personal space to ensure privacy and confidentiality. To further protect anonymity, we did not ask the officers to provide their names or addresses. All survey activities took place in April 2015.

In terms of sampling, we aimed at the representation of officers across all levels of rank. To this end, individual officers were selected in a stratified way. First, we purposively invited regional-level officers to participate in the survey because of their leading position. 
Second, we also purposively included the leading police officers of the district headquarters in the survey. Finally, we randomly sampled police stations within districts: Half the officers in our sample come from small stations (with up to 10 officers) and $70 \%$ of them from mid-sized stations (with up to 25 officers). We introduced random participation at the police station level by randomly picking the day of the survey resulting in local participation based on availability or presence. At the local level we do not expect any systematic selection of participants into our sample since the police stations only have few officers. As motivated, we applied this sampling procedure to have a stratified sample of officers that represents the full spectrum of police work, functions, positions, and hierarchies.

The survey among police officers had two parts. In the first part, officers reported their basic socio-economic characteristics together with information about their work experience and some basic facts about the staffing and equipment of their police station. In the second and core part, officers were asked to review twelve vignette cases and questions about the perceived institutional environment and effectiveness of the police. The vignettes were adapted to the Ugandan context based on the earlier versions developed by Klockars et al. (2000, 2006) and Kutnjak Ivković (2005a, 2005b). Adaptation to the local context was necessary since, for example, the offering of small gifts on holidays such as Christmas is not perceived as an indication of corruption. Furthermore, we wanted to test to what extent the police complaint form, introduced by the Ugandan police prior to our survey, was accepted among the police. Therefore, we included a case about the application of the form. Similarly, the peaceful monitoring of demonstrations and the professional clearing of potential conflicts, while accepting the right to demonstrate, was another aspect of policing that we considered necessary assessing in the specific Ugandan context. The complaint form as well as the monitoring of demonstrations were topics that were perceived as very relevant by the locals. Thus, the cases that we deployed were co-developed with our local research partner, pretested with the police and adjusted to the local context. Importantly, on purpose we opted for the inclusion of case scenarios with cultural load. For example, the originally proposed case scenarios contain the case of a burglary in a jewelry shop (Klockars et al., 2000, 2006). Since jewelry shops are not common in local Uganda there would not have been any value in presenting such a scenario. Consequently, we introduced a burglary in a general merchandise shop. We specified the goods relative to locally know units and products in an attempt to contextualize and to ensure that the police officers responding to the case had a good sense of the stolen value. Similarly, we included the category "Reported severe crimes against individuals not followed up upon" since this was identified by civil society organizations as a 
major problem in Uganda. Thus, we were taking a needs-based and context-specific approach when replacing existing and integrating new cases. We consider this the strength of our analysis since the vignettes are the result of an in-depth analysis of the local context and conditions prior to the implementation of the case scenarios at scale.

We presented the vignette cases in random order to avoid an order by severity. For the sake of exposition in this chapter, we have grouped the cases into six categories of two cases each: the first group focuses on the code of conduct among police officers, the second on bribery, the third on theft, the fourth on the refusal to register a complaint against the police, the fifth on severe crimes against individuals that are not followed up by the police, and the sixth on undue force used by the police against suspects and demonstrators (table 1).

$<$ Table 1 about here>

The wording of the vignette cases can be found in Appendix 2. Note that we implemented the vignettes in the context of an impact assessment of the Police Accountability and Reform Project (for detailed results see Hout et al., 2016; Wagner et al., 2019; Hout et al. 2019). Moreover, the original wording of the vignette cases allowed for the random variation of the gender of the portrayed police officers, perpetrators, and victims. The related gender dynamics are assessed in a separate article (Wagner et al., 2017). We show there that neither the randomly varying gender of the police officer nor the randomly varying gender of the victim depicted in the vignette cases are related to the judgment of police malpractice, or to suggested disciplinary measures. What we do find is that male respondents tend to be stricter in their assessment of the hypothetical cases. Overall, the results show that gender perceptions do not differ between male and female police officers. Based on this finding, we do not expect that the survey experiment has any repercussions for the analysis at hand. Most importantly, since the gender variations were introduced randomly and balancing holds well across randomly introduced male and female gender attributes, we are methodologically on the safe side.

In our survey we obtained comprehensive answers to five of the original seven evaluative questions introduced by Klockars et al. The police officers answered the following questions for each case:

1. How serious do YOU consider this behavior to be? (Referred to as 'Own seriousness') 
2. Do you think YOU would report a fellow police officer who engaged in this behavior? (Referred to as 'Own reporting')

3. How serious do MOST POLICE OFFICERS IN YOUR OFFICE consider this behavior to be? (Referred to as 'Colleagues' seriousness')

4. If an officer in your agency engaged in this behavior and was discovered doing so, what if any disciplinary measure do YOU think SHOULD follow? (Referred to as 'Disciplinary measure that should follow')

5. Would this behavior be regarded as a violation of official policy in your agency? (Referred to as'Regarded as violation of official policy')

In line with the existing literature the possible answer categories range from 1 to 5 on a Likert scale. Responses to questions 1 and 3 had the answer categories 'not at all serious' [1] to 'very serious' [5]. Questions 2 and 5 could be answered on a categorical scale from 'definitely not' [1] to 'definitely yes' [5]. Question 4 on disciplinary measures comprised six categories in ascending order of severity of the response: 'none' [1], 'verbal reprimand' [2], 'written reprimand' [3], 'period of suspension without pay' [4], 'demotion in rank' [5] and 'dismissal' [6].

In addition, information about the officers' perception of the institutional environment and police effectiveness was collected by using a set of ten Likert scale questions. The questions about the perceived institutional environment and police effectiveness include the following aspects:

1. What is the perceived crime level in the local community?

2. Do the police treat young people the same as older people?

3. Do the police treat poor people the same as rich people?

4. Do the police treat men the same as women?

5. What is the level of confidence in the officer's own work?

6. What is the level of confidence in the work of the police in general?

7. Do the police always have the duty to make people obey the law?

8. Do the police perform a good job in treating people fairly and with respect?

9. Do the police perform a good job in managing crime?

10. Are the police corrupt?

These questions were chosen because our survey was implemented in the context of Dutch policies and funding decisions focusing on rule of law and control of corruption initiatives in 
Uganda. The multi-facetted aspects of good governance to reduce corruption were the guiding principles for Dutch financial involvement. The above ten questions were selected to capture good governance at the level of the police. On purpose we focused on aspects of the perceived institutional environment and police effectiveness. Our approach is in line with Miles-Johnson and Pickering (2018) who assess police recruits' perceptions of trust in minority group members. Our first four questions are motivated by the idea that police officers evaluate their work relative to the broader community they live and work in and the different groups that constitute that community. In addition, question 1 is motivated by the finding that police officers have positive perceptions of their work when crime is reduced (Bradford et al., 2013). Questions 5 and 6 are motivated by the fact that by and large the existing literature assesses confidence and relatedly trust in the police (Balliet and Van Lange, 2013; Bradford, 2014; Mastrofski et al., 2016) but the aspect of own confidence receives less attention. We argue that police officers can only view their role as positive if next to the perception of the police by the public, the officers themselves have confidence in their work and the work of their colleagues. In addition, existing evidence shows that police officers perceive a sense of effectiveness when they are perceived as upholding the law (Jenks et al., 2012). This rational motives question 7. Questions 8 and 9 are meant to capture procedural fairness and justice, as

well as policing that is equitable across all members of society (Miles-Johnson, 2016). Finally, question 10 asks for a self-assessment of the level of corruption at the police. Our approach is related to the work by Carr and Maxwell (2018) who assess officers' perceptions of organizational justice on officer trust in the public. Similar to our research they employ multiple perception questions. Yet, their focus is different since they consider the relationship with the supervisor, as well as distributive and procedural justice within the police force.

Individually and jointly our set of 10 questions allows us to assess perceptions of the institutional environment and effectiveness of the police. Thus, in our analysis we combine the information we have obtained from the vignette cases with the questions about perceived institutional environment and effectiveness to see how these perceptions affect police officers' attitudes toward misconduct and their willingness to report such behavior.

\section{Descriptive statistics}

\section{Background characteristics of the police officers and the districts}

Descriptive statistics of the background characteristics of the respondents and related to district characteristics are presented in table 2, Panel A. 
The data on individual characteristics of the respondents provide an overview of the police officers included in our research. The average officer in the sample is almost 42 years old. Slightly less than a quarter of the respondents are female. Most of the officers are married $(84 \%)$ and a similar percentage of the interviewees are head of a household (84\%). They live in a household with, on average, almost 7 people. However, variation in household size is substantial (the standard deviation is 4). Almost half of the officers have completed secondary education, while $27 \%$ finished advanced secondary education and $25 \%$ have a higher education degree. Less than 3\% have completed only primary education. Thus, our sample consists of prime-age individuals, who are predominately male and have a fairly high level of education relative to the overall population of Uganda. We control for all these aspects in the multivariate analysis to ensure that our findings are not influenced by variations in omitted background characteristics.

In terms of economic well-being, we observed the following. Around $60 \%$ of the respondents earn between UGX 300,000 and 500,000 on a monthly basis. ${ }^{1}$ Another almost $25 \%$ of the sample earn UGX 500,000 and more. The average respondent owns 1.34 mobile phones and has almost 2 habitable rooms at home. The inclusion of these economic variables in the analysis ensures that our results of interest are not influenced by differences in income that might be related to differences in perceptions.

Sports activities are reported by $53 \%$ of the respondents and almost half of the respondents indicate being a member in a club or community organization. The latter two aspects serve as controls for the activity levels of the respondents and their readiness to actively engage in activities next to their work. We consider it necessary to control for these aspects since perceptions are linked to behavior not only at work but also in private life.

Work-related characteristics are presented in Panel B of table 2. They form part of the second set of control variables. We collected information on the section of the police force the respondents are placed in, the length of their career as a police officer, and the infrastructure at their station (number of rooms, number of cars/motorcycles/bicycles). The average police officer has spent 18.8 years in service. Unsurprisingly, there is a considerable variation in this variable (the standard deviation is 10.5). The majority of the respondents, that is $46 \%$,

\footnotetext{
${ }^{1}$ This roughly corresponds to a range of US $\$ 80$ and 135 based on the UGX/US $\$$ exchange rate of 0.00027 from January $31^{\text {st }}, 2019$. According to World Bank (2019) data, per capita gross national income in Uganda was US\$ 50 per month in 2017.
} 
perform general duties. Officers working in the investigation section make up $26 \%$ of the sample. The remaining officers work for other sections, including traffic police and intelligence departments. The police stations they are placed in vary greatly in size: on average they have 12.8 rooms but the standard deviation is 9.3. Police motorcycles are the most common means of transport for the officers. The average station has 6.8 motorcycles, while it also possesses 1.5 cars and 2.1 bicycles.

Finally, Panel C of table 2 presents some district-level characteristics. We selected the 600 respondents from 10 districts, while aiming to obtain pairs of two similar districts in the district selection. To assess the district socio-economic and crime related situation we collected district level administrative data for all 10 districts from the local administrations: The average district has roughly 420,000 inhabitants and grows at an annual rate of $2 \%$, while about one-fifth of the population is living in poverty. The average Gini inequality index is 0.4 (District level administrative data). The districts are ethnically fairly homogeneous, as is shown by the finding that more than $70 \%$ of the population at district level belong to the district's main ethnic group. The number of police officers per 100,000 inhabitants is $133 .^{2}$ The crime rate is 338.2 and the homicide rate is 8.6 (District level administrative data). Similar to the individual-level characteristics we control for the district-level characteristics in the multivariate analysis to avoid that our results are biased as a consequence of differences across districts.

\section{Descriptive statistics of the outcome variables derived from the vignette cases}

The descriptive statistics of the five outcome variables that we collected for the twelve vignette cases are presented in table 3. This table presents the average for the five outcomes across all twelve cases, thus resulting from 7,200 observations (12 cases*600 police officers). A detailed, case-by-case assessment is presented in table A1 in Appendix 1. We present the simple averages resulting from the Likert scale answers.

\section{$<$ Table 3 about here>}

\footnotetext{
${ }^{2}$ In comparison, the average EU country had about 318 police officers per 100,000 inhabitants in 2016. The EU member state with the lowest number of officers is Finland, which had 137 officers per 100,000 inhabitants in 2016 (EuroStat, 2016).
} 
We observe that the responses to all five questions range on average between 3.9 and 4.4, which suggests that the depicted cases of misbehavior are taken seriously by the officers. We find the lowest average Likert rating (3.9) for the evaluative question about the disciplinary measure that should follow and the highest average rating (4.4) for the evaluative question whether the behavior is a violation of official policy. Moreover, we observe that the officers think that they themselves consider the depicted cases of misconduct slightly more seriously compared to their colleagues (table 3).

Concerning the detailed descriptive statistics per case, our findings are in line with observations of other researchers in the field (cf. Kutnjak Ivković and Haberfeld, 2015: 340346). We find that there is a sorting of assessments by case severity (see table A1 in Appendix 1). The first two vignette cases, on police code of conduct, are judged rather mildly. Receiving holidays in exchange for repairing a supervisor's car is assessed moderately negatively (the average score is 3.72), although officers tend to be generally aware that such behavior violates official policy (average score of 4.24), which they would report (average score of 4.06). The misbehavior described in the second case, related to covering a drunk colleague who caused an accident, is by and large seen as a light offense.

Cases of bribery are depicted in the second group of vignettes. Case 3, on accepting gifts while on duty, receives the lowest Likert scores of all cases. All respondents score only slightly higher than the neutral position (a value of 3 ) when it comes to reporting a colleague. Case 4, related to the acceptance of bribes, is evaluated very critically, as indicated by the score of 4.4. Moreover, police officers tend to agree that this misbehavior should be subject to stringent disciplinary action (average score of 4.3).

The third group of cases contains incidences of theft. Case 5 (the misappropriation of money from a lost wallet) and case 6 (illegal enrichment when investigating a burglary) are judged quite harshly with scores of 4.0 and 4.5, respectively, and a great majority of respondents indicate they would report such misbehavior of a colleague. Case 6 is the instance of misbehavior that would require the toughest disciplinary response in the view of the police officers: the average score on the disciplinary action scale is 5.1.

Overall, the first six cases suggest that police officers have a clear idea about acceptable and non-acceptable police behavior: acceptance of bribes and theft are evaluated more critically than violations of the police force's code of conduct. In most cases, officers see themselves as more critical of misbehavior than their colleagues. Responses to the question whether particular forms of misbehavior violate official policy indicate the existence 
of a gap between formal rules and actual practices since on average they tend to receive the highest score within a case.

The next two cases depict situations in which police officers refuse to register complaints. The refusal to register a complaint and the humiliation of the complainant (case 7) is judged rather mildly (score of 3.6), but the arrest of a complainant on false grounds (case 8 ) is considered unacceptable by the majority of officers (score of 4.0). This is in line with our expectations and shows the internal coherence of the vignette cases.

Lastly, cases of reported severe crimes against individuals without adequate follow-up by the police (cases 9 and 10), and of the use of undue force (cases 11 and 12) are assessed seriously or very seriously. Case 9 , which involves the refusal to register the mistreatment of a wife, is considered to be one of the most serious forms of police misbehavior (score of 4.3). Police officers agree that such misbehavior should be subject to strict disciplinary action (score of 4.0). Although the failure to follow up on a reported murder (case 10) is assessed as a serious form of misconduct (score of 3.9), police officers do not feel such behavior should be punished very severely (score of 2.7 on the disciplinary action scale). The two cases of undue police force are considered to be serious, as they are rated with a score of 3.9 (case 11) and 4.1 (case 12). In these instances, disciplinary action should be quite harsh, according to the average police officer, whose response leads to a score of 3.9 on the disciplinary action scale in both cases.

\section{Descriptive statistics of the perceived effectiveness of the police}

As initially motivated we want to study the vignette case assessments in relation to the perceived effectiveness of the police. To do so, we build on the ten Likert scale questions about the perceived institutional environment and police effectiveness that were introduced above in section 4 . Table 4 presents the descriptive statistics related to the ten perception variables on the institutional environment and police effectiveness. All variables are measured on a five-point Likert scale, similar to the measurement of the responses to the vignette cases.

$<$ Table 4 about here>

The first item among the perception variables inquiries about the level of crime in the local community and in Uganda as a whole. The average score of 2.5 on this item indicates that police officers perceive some problems with regard to the overall crime level in the country, while, at the same time, they consider the problems to be moderately important. The 
next aspect we consider refers to the question whether the police treat young people the same as old people. The average rating of 4.0 suggests that the majority of the police officers thinks that younger people are treated better. In contrast, they do not on average feel that there is a big discrepancy in the treatment of poor and rich individuals (average score 3.5). Police officers tend to perceive the treatment of men as slightly more favorable compared to the way women are treated (score of 3.8).

Confidence in the police officers' own work is high as shown by the average score of 4.6 on the fourth perception component. Police officers' confidence in the work of their fellow officers is also high, albeit 0.2 points lower than confidence in their own performance, suggesting that there is some sense of an esprit de corps. When it comes to the role of the police, the officers are very clear that it is always their duty to make people obey the law. This component obtains the highest overall score at 4.7. Moreover, the great majority of interviewed police officers think the police are doing a good job in treating people fairly and with respect (average score of 4.1).

Next we turn to the management of crime: the average score of 4.30 is even 0.2 points higher than the average on the fairness and respect question, which suggests that the officers have a high opinion about the quality of policing. Here one may see some tension with the observation by the Ugandan population that the police are the most corrupt institution in the country, which was reported above in section 3. Item 9 of our perception variables addresses perceived corruption in the police force. In the light of the self-congratulatory attitude of police officers, it is not surprising that officers tend to downplay the seriousness of corruption. The statement 'The police are corrupt' receives an average score of 2.6, which suggests that, despite their positive assessment of the work of the police, officers seem to be moderately aware that of problems with corruption in the police force.

Taken separately, the ten perception questions provide insight into how individual police officers perceive different dimensions of the institutional environment and police effectiveness in Uganda. The responses to the questions are interesting in themselves but they do not give us a complete picture of the perceived overall level of the institutional environment and police effectiveness. For this reason, the next step in the analysis is to correlate the ten questions in order to assess to what extent they are related. Results of the correlation analysis are presented in table 5.

$<$ Table 5 about here> 
Visual inspection of the correlation coefficients shows that most of the ten perception indicators are highly correlated. The correlations range between -0.353 and 0.571 . Most items are positively correlated, but the perceived level of crime in the community and the perceived level of police corruption show negative correlations with the other variables. The magnitude of the pair-wise correlations and the fact that all but one are highly statistically significant, leads us to the conclusion that the chosen indicators of the perceived institutional environment and police effectiveness are jointly relevant. This result suggests that taken together the indicators may be used as a measurement of the self-assessed quality of work of the police.

On the basis of the results reported in table 5, we include the indicators using two approaches. Firstly, we built an index that expresses the average score across all ten items. Secondly, we retrieved the first principal component of the variables and use this component score as indicator. The bottom two rows of table 4 present the descriptive statistics using the two approaches. The average index of the ten perception variables is 3.9 with a standard deviation of 0.5 . This indicates that the overall perception of police effectiveness borders on 'good' and is thus rather favorable. The average PCA index is 0.0 with a standard deviation of 1.8. The PCA index shows high variability since it is designed to accumulate maximum variability over the ten perception components. It ranges from a minimum of -6.8 to a maximum of 2.7. The next section contains a more detailed discussion of the findings of the multivariate analysis involving the responses to the questions on the perception of police effectiveness and the evaluative questions relating to the vignette cases.

\section{Empirical model}

We set up a multivariate empirical model to analyze the relationship between the evaluative questions on police misbehavior and the measures of the perceived institutional environment and effectiveness of policing. The following model is used to estimate the evaluative response of every police officer $i$ in district $d$ responding to case $c$ :

$$
Y_{i d c}=a_{0}+a_{1} \text { Effect }_{i d c}+a_{2} \text { Socio }_{i d c}+a_{3} \text { Work }_{i d c}+a_{4} \text { District }_{d c}+\lambda_{c}+\varepsilon_{i d c},
$$

where the outcome variable $Y_{i d c}$ represents one of the five evaluative responses to the vignettes cases. The coefficients of interest are collected in vector $a_{1}$. These are the coefficients associated with the individual components of the perceived institutional environment and police effectiveness, denoted as Effect $t_{i d c}$. In addition, we include a series of control variables: the individual characteristics of the respondents are collected in Socio $_{i d c}$, the 
work-related characteristics in Work idc $_{\text {and }}$ and district characteristics are denoted by District $_{d c}$. For the estimation of this model we pool all vignette cases since our primary interest is not to assess differences across vignettes but to relate the average rating of the vignette responses across cases to the perceived institutional environment and police effectiveness. In order to account for the fact that the vignettes display cases of differing severity, we control for case specific effects $\lambda_{c}$, which implies that we include 11 case specific effects, leaving one case specific effect as the excluded category. Standard errors $\varepsilon_{i d c}$ are clustered at the individual level since the case-specific residual is likely to be correlated within officers' responses.

In addition, we estimate a model where we replace the matrix of the ten independent perceived institutional environment and police effectiveness measures with a single combined index. First we construct the average level of police effectiveness: Effect $_{i d c 1}+$ Effect $_{i d c 2}+\ldots$ + Effect $\left._{i d c 10}\right) / 10$. This index, based on the average across the individual items, gives equal weight to all its constituting components.

Second, we use a method that is considered superior and is based on the construction of an index using principal component analysis. In principal component analysis we employ an orthogonal transformation to convert our ten correlated effectiveness variables by means of a statistical procedure into linearly uncorrelated variables called principal components. This transformation is based on maximizing the variance in the first principal component, so that this first component reflects the internal structure of the police effectiveness variables in a way that best explains their variance and contains most of the information across the original components. We employ both the average index and the principal component index separately to gauge the robustness of the results. The index creation is supported by earlier research, which attempted to derive a scale of (seriousness of) police misconduct and indicated that the vignettes appear to represent a one- or two-dimensional space (cf. Jenks, 2014: 328; Lee, 2013: 390). Based on the existing literature, we opted for the inclusion of only one dimension since the average index is one-dimensional and we aimed for a straightforward and direct comparison of the results.

As an additional assessment of the robustness of our results, we estimate the three models that were outlined above with district fixed effects instead of including the district characteristics. Results of the latter three analyses are presented in Appendix 1 in tables A2 (for model 1, using detailed perception components) and A3 (for model 2, using the average perception index, and model 3, applying the index derived from principal component analysis). 


\section{Results}

The results of our analyses are presented in tables 6 and 7. Next to the ten perception variables (table 6) or the perception indices (table 7), all regression analyses contain the above-mentioned individual, work-related, and district-specific control variables as well as the vignette fixed effects. These coefficient estimates are not presented for the sake of brevity and clarity of exposition.

We start by assessing the relationship between the evaluative responses to the vignette cases and the individual perception components. The results that are summarized in table 6 show not only that the different evaluative responses capture different aspects of police integrity, but also that the perceptions of the institutional environment and police effectiveness contain a variety of elements. This implies that across the five evaluative responses we find correlations with different aspects of police effectiveness.

$<$ Table 6 about here>

Column 1 of table 6 displays the relationship between the response to the question 'How serious do YOU consider this behavior to be?' and the ten perceived institutional environment and police effectiveness components. As can be seen, the perceived severity of misbehavior is associated significantly with the perception that the police treat people fairly and with the perceived corruption level. The coefficient estimate of 0.150 indicates considerable practical relevance: an increase of one standard deviation in the perceived fair treatment of people $(\mathrm{sd}=1.003$, see table 4, row 8) explains almost $10 \%$ $(=[0.150 * 1.003] / 1.546 * 100)$ of the standard deviation in the perceived severity of the misbehavior. Similarly, an increase of one standard deviation in the perceived corruption level $(\mathrm{sd}=1.420$, see table 4 , row 10$)$, which reflects a decrease in perceived corruption, explains $6.5 \%(=[0.071 * 1.420] / 1.546 * 100)$ of the standard deviation in the perceived severity of the misbehavior. Taken together these two components of perceived police effectiveness explain more than $15 \%$ of the standard deviation of responses to the evaluative question about won seriousness. This is a sizeable effect and suggests that case evaluations are related to two aspects of perceived functioning of the police, namely the respectful treatment of people and the perceived level of corruption.

The likelihood that police officers would report the misbehavior of a fellow officer shows a statistically significant relationship to the confidence in the work of the colleagues 
(significant at the 10\% level) and to the perceived discrepancy in the treatment of men and women (very strongly related and significant at the $1 \%$ level). A one standard deviation increase in the perceived discrepancy in the treatment of men and women $(\mathrm{sd}=1.203$, see table 4 , row 4) explains $11.6 \%(=[0.124 * 1.203] / 1.289 * 100)$ of the standard deviation of the evaluative question about report a fellow police. Similarly $6.3 \%(=[0.091 * 0.889] / 1.289 * 100)$ of the standard deviation in reporting is explained by a one standard deviation increase in the confidence that police officers have in the work of their colleagues $(\mathrm{sd}=0.889$, see table 4 , row 6). This shows that perceived police effectiveness, in particular related to the perception that both sexes are treated differently and the confidence in the performance of colleagues, seems to impact on officers' responses to the question about the reporting of misbehavior.

When we turn to the police officers' view of their colleagues and how serious they think most police officers in their office consider the depicted misbehavior to be, the outcome variable appears to be impacted by three variables of perceived police effectiveness. All are linked to the treatment of people. Firstly, the assessment of the seriousness of misbehavior as expected from colleagues seems to be associated negatively with the perceived favoring of young people. Secondly, colleagues' assessment of the seriousness appears to be associated positively with the perceived favoring of men, while, thirdly, it is associated positively with the fair and respectful treatment of people. While only the association with the third variable seems strong, we need to gauge the relationship relative to the measurement of the variables as presented in the descriptive statistics (table 4). A one standard deviation increase in the first and second variable explain $5.7 \% \quad(=[0.074 * 1.095] / 1.423 * 100)$ and $6.6 \%$ $(=[0.078 * 1.203] / 1.423 * 100)$ in the standard deviation of the colleagues assessment, respectively. Taken together the three components of perceived police effectiveness explain $23.6 \%(=[0.074 * 1.095+0.078 * 1.203+0.161 * 1.003] / 1.423 * 100)$ of the standard deviation of the evaluative question about colleagues' seriousness.

The fourth evaluative question deals with the disciplinary measure that should follow particular forms of misbehavior. No single component related to the perceptions of the institutional environment and police effectiveness appears to have any explanatory power visà-vis the imposition of disciplinary sanctions.

Finally, we assess whether police officers see the depicted forms of misbehavior as a violation of official policy in their agency. This evaluation appears to be correlated with four of the perceived institutional environment and police effectiveness components, namely confidence in own work, confidence in the work of colleagues, the perception that police officers always have the duty to enforce the law, and the perceived corruption level. Except 
for the confidence in the work of colleagues, coefficient estimates are statistically significant at the 1 or $5 \%$ level. Together they explain $27.7 \% \quad(=[0.088 * 0.835+0.068 * 0.889+$ $0.153 * 0.701+1.42 * 0.064] / 1.199 * 100$ ) of the standard deviation in this outcome variable.

Our findings indicate that overall there is no doubt that the assessment of the vignette cases is not only linked to individual, work-related, and police infrastructure variables (which are not shown for the sake of brevity), but that the perceived institutional environment and police effectiveness variables have additional explanatory power for policy integrity. There is no single item that captures the perception of the institutional environment and police effectiveness fully, but seven of the ten perception variables seem to play a role in relation to different evaluative positions.

Linking the five evaluative responses to the vignette cases to the ten individual components of the perceived institutional environment and police effectiveness might be misleading. We might end up emphasizing only selected dimensions of the perceived institutional environment and police effectiveness despite the fact that we have shown in the pair-wise correlations that none of these components should be looked at individually since the majority are heavily interrelated and only represent different aspects of some larger underlying concept. For this reason we now turn to the assessment of the combined indices of the perceived institutional environment and police effectiveness. Results of the analyses are presented in table 7. All five evaluative responses appear to be correlated positively with both effectiveness indices. Our results show that of the five evaluative variables, two are positively and statistically significantly correlated with both the average police effectiveness index and the PCA index, while two are only statistically significantly correlated with the average index and one is only statistically significantly correlated with the PCA index.

$<$ Table 7 about here>

Looking into the analysis of the evaluative responses to the vignette cases one-by-one (Table 7), we find that for the assessment of the severity of the case a one standard deviation increase in the average index $(\mathrm{sd}=0.459$, see table 4 , row 11) explains $6 \%$ $(=[0.203 * 0.459] / 1.546 * 100)$ of the standard deviation in the assessed severity of the case. We do not find a significant relationship between the PCA index and the severity of the case. When it comes to the reporting of a fellow police officer, we find a stronger relationship (0.378), which means that a one standard deviation increase in the average index $(\mathrm{sd}=0.459$, see table 4 , row 11$)$ explains $13 \%(=[0.378 * 0.459] / 1.289 * 100)$ of the standard deviation in 
the reporting of a fellow officer. We further find a statistically significant relationship with the PCA index. A one standard deviation increase in the PCA index ( $\mathrm{sd}=1.820$, see table 4, row 12$)$ explains roughly $14 \%(=[0.098 * 1.820] / 1.289 * 100)$ of the standard deviation in reporting. Thus, while the coefficient estimates differ for the different indices, both indices are similar in terms of explanatory power when it comes to the reporting outcome. This result stems from the fact that the indices also have different distributions as can be gauged from a comparison of the differences of the means and standard deviations. For the evaluative question about colleagues' seriousness we also find that both indices are statistically significant. Again they explain similar portions of the standard deviation in that question. The average index explains $12 \%(=[0.371 * 0.459] / 1.423 * 100)$, while the PCA index accounts for $13 \%(=[0.104 * 1.820] / 1.423 * 100)$. With respect to officers' position on disciplinary measures, only the PCA index is significantly related to the evaluative question. The PCA index explains about $4 \%(=[0.031 * 1.820] / 1.514 * 100)$ of the standard deviation of the question about disciplinary measures. This finding is in line with the analysis of the one-by-one analysis of the perceived institutional environment and police effectiveness (table 6). This showed that none of the perception variables was individually significant. The final evaluative question relates to the official policy in the agency. For this outcome only the average index has explanatory power.

Despite variations in the associations between police integrity and the presented indices, there is no doubt that the two aspects are related yet sensitive to the type of measurement and aggregation. By way of conclusion, we argue that different aspects of the perceived institutional environment and police effectiveness are related to different evaluative dimensions of police integrity. The relationship between the different aspects of police integrity and the index of perceived police effectiveness is sensitive to the construction of the index demonstrating that a summary index of perceived police effectiveness does not necessarily reflect the associations of its constituting components completely. Overall, we infer that the subjective perceptions of the institutional environment and police effectiveness undoubtedly feed into attitudes of police integrity suggesting that the vignettes can serve as a tool to channel and represent the individual subjective biases in a coherent form.

As indicated above, an additional robustness test is presented in tables A2 and A3 in Appendix 1. In the analyses underlying these tables, the district control variables are replaced with district fixed effects. The results are almost identical to the findings presented earlier in this section, not only in terms of the direction of the effect and its statistical significance, but 
also in terms of magnitude. These additional tests make us confident about the reliability of our results.

\section{Conclusion}

In this chapter, we have attempted to contribute to the burgeoning literature on police integrity by assessing what is the relationship between Ugandan police officers' perceptions of the institutional environment and the effectiveness of policing on their evaluations of specific forms of police misbehavior. Using data collected in a survey involving 600 police officers in Uganda, we focused on 10 perception variables, which we analyzed separately and collectively. The results of our analyses show that there are indeed concrete signs that the perceived quality of the institutional environment and police effectiveness is impacting on evaluative dimensions of police integrity. Our research shows that the perceived quality of the institutional environment and perceptions of police effectiveness are impacting the evaluations of police misbehavior. The perceptions that are most strongly linked to the evaluative questions about police integrity are the assessment of the differential gender treatment, police officers' confidence in the work of colleagues, the view that the police treats people fairly and with respect and the perceptions about corruption in the police force.

While all of these factors relate to several dimensions of police integrity, our results also demonstrate that there is not a one-to-one relationship between the assessed dimensions of the perceived environmental context and police effectiveness, on the one hand, and the evaluations of misbehavior by police officers, on the other. When combining the ten dimensions of the perceived institutional environment and police effectiveness in two indices (an average index and a principal-component index) and analyzing the relationship with the evaluative responses to the vignette cases, we find further evidence that the subjective perceptions of the institutional environment and police effectiveness feed into attitudes toward police integrity. At the same time, we find that the relationship between the evaluative questions about police integrity and the index of perceived police effectiveness is sensitive to the construction of the index. Thus, while the vignettes are meant as a tool to reduce subjective biases in the evaluation of police misbehavior, the assessment of the vignettes is not free of individual perceptions. This suggests that the vignettes can be seen as means to channel and represent the individual subjective biases in a coherent and comparable form.

We consider the results presented in this chapter only as a first attempt at linking police integrity to perceptions about the institutional environment and policing effectiveness. In particular, our research is aiming at complementing earlier studies on the impact of various 
factors on the attitudes of police officers to corruption and misconduct, such as the police's organizational culture and characteristics (Eitle et al., 2014; Kucukuysal, 2008; Kutnjak Ivković and Sauerman, 2015), their disciplinary environments (Lee et al., 2013; Kutnjak Ivković and Khechumyan, 2014; Cheloukine et al., 2015; Kutnjak Ivković et al., 2016; Kuo, 2018), disciplinary fairness and organizational justice (Kutnjak Ivković and O'Connor Shelley, 2010; Wolfe and Piquero, 2011; Kutnjak Ivković and Sauerman, 2013; Long et al., 2013; Myhill and Bradford, 2013; Porter et al., 2015), individual and work related characteristics (Reynolds and Helfers, 2018; Lee et al., 2013; ) as well as police cynicism (Bucak, 2012).

Our results suggest new avenues for research into the relationship between the evaluative positions of police officers and perceptions of institutional environment and effectiveness. An obvious first step would be to theorize police effectiveness more thoroughly. As suggested by the results obtained in our principal component analysis, there appears to be an underlying dimension of police effectiveness in the perception variables (cf. table 5). A more systematic review of the literature of public service effectiveness may bring out a wider range of indicators, and possibly also dimensions that would be useful in research on perceptions of police effectiveness.

Another way to enrich the analysis of police effectiveness could be the combination of research using vignettes of police integrity with client surveys at the level of police stations of units. In such client surveys, individual citizens who had contact with the police (either for solving their problems or because they were suspected of crimes or misdemeanors) could be asked to provide their assessment of the performance of the police. As a next step, average police station or unit level vignette scores could be associated with the perceptions of the public.

Finally, researchers could attempt to draw on different strands of research, such as for instance the studies done by Waddington et al. (2009) on police culture, to get better and more nuanced insight into the perceptions of police officers about what is considered to be effective policing. Such an approach may possibly build bridges to more detailed psychological research to better understand the perceptions of the police. If possible, officers could be requested for input at different stages of their career in order to incorporate the impact of socialization during years of service.

\section{References}


Anderson, D.M. and Fisher, J. (2016) 'Authoritarianism and the Securitization of Development: The Case of Uganda', in Hagmann, T. and Reyntjens, F., eds, Development without Democracy? Foreign Aid and Authoritarian Regimes in Africa, London: Zed Books, pp. 67-90.

Andreescu, V., Keeling, D.G., Vito, G.F. and Voinic, M.C. (2012) 'Romanian and American police officers' perceptions of professional integrity and ethical behavior', Revista Romana de Sociologie 23(3/4): 185-207.

Balliet, D., and Van Lange, P. A. (2013) 'Trust, conflict, and cooperation: A meta-analysis', Psychological Bulletin, 139(5): 1090-112.

Barkan, J.D. (2011) Uganda: Assessing Risks to Stability, Washington, D.C.: Center for Strategic and International Studies.

Basheka, B.C. (2013) 'Public Administration and Corruption in Uganda', in VyasDoorgapersad, S., Lukamba-Muhiya, T. and Peprah Ababio, E., eds, Public Administration in Africa: Performance and Challenges, Boca Raton: CRC Press, pp. 45-81.

Bucak, S. (2012) An Examination of Police Cynicism in Turkey and Its Impacts on Officers' Perception of Corruption, $\mathrm{PhD}$ thesis, University of Chicago, https://indigo.uic.edu/handle/10027/9738 (accessed 12 February 2019).

Bradford, B. (2014) 'Policing and social identity: Procedural justice, inclusion and cooperation between police and public', Policing and Society 24(1): 22-43.

Bradford, B., Jackson, J., and Hough, M. (2013) 'Police Futures and Legitimacy: Redefining "Good Policing"', In J. Brown, Ed, Future of Policing, Oxon: Routledge.

Carr, J. D. and Maxwell, S. R. (2018) 'Police officers' perceptions of organizational justice and their trust in the public', Police Practice and Research 19(4): 365-379.

Cheloukhine, S., Kutnjak Ivković, S., Haq, Q. and Haberfeld, M.R. (2015) 'Police integrity in Russia', in Kutnjak Ivković, S. and Haberfeld, M.R. (eds) Measuring Police Integrity Across the World: Studies from Established Democracies and Countries in Transition, New York: Springer, pp. 153-182.

Commonwealth Human Rights Initiative (2006a) A Review of the Uganda Police Force Budget and its Effects on Crime Management, http://www.humanrightsinitiative.org/publications/police/uganda_report.pdf (accessed 12 February 2019).

Commonwealth Human Rights Initiative (2006b) The Police, the People, the Politics: Police Accountability in Uganda, http://www.humanrightsinitiative.org/publications/police/uganda_country_report_2006.pdf (accessed 12 February 2019).

Coulangeon, P., Pruvost, G., Roharik, I. and Matthews, T. (2012) 'Professional Ideologies: A Latent Class Analysis of Police Officers' Opinions on the Role of the Police', Revue Française de Sociologie (English Edition) 53(3): 347-380. 
Economist (2018) 'Uganda's politicised police force is not reducing crime', https://www.economist.com/middle-east-and-africa/2018/07/05/ugandas-politicised-policeforce-is-not-reducing-crime (accessed 12 February 2019).

Eitle, D., D'Alessio, S. J., and Stolzenberg, L. (2014). 'The Effect of Organizational and Environmental Factors on Police Misconduct', Police Quarterly 17(2): 103-126.

EuroStat (2016) 'Police, court and prison personnel statistics', https://ec.europa.eu/eurostat/statistics-

explained/index.php?title=Police,_court_and_prison_personnel_statistics $\quad$ (accessed 12 February 2019).

Golooba-Mutebi, F. and Hickey, S. (2013) 'Investigating the Links Between Political Settlements and Inclusive Development in Uganda: Towards a Research Agenda', ESID Working Paper 20, Manchester: Effective States and Inclusive Development Research Centre.

Hout, W., Brouwers, R., Fisher, J., Namara, R., Schakel, L. and Wagner, N. (2016) Policy Review Good Governance: Democratisation, Promotion of Rule of Law and Control of Corruption - Uganda Field Study, Final Report for the Policy and Operations Evaluation Department (IOB), Ministry of Foreign Affairs, The Netherlands.

Hout, W., Wagner, N. and Namara, R. (2019) 'Holding Ugandan Police to Account: Case study of the Police Accountability and Reform Project', in Bergh, S., Pellisserey, S. and Sathyamala, C., eds, The State of Accountability in the Global South: Challenges and Responses, Cheltenham: Edward Elgar, forthcoming.

Jenks, D., Johnson, L.M. and Matthews, T. (2014) 'Examining police integrity: Categorizing corruption vignettes', in Guzman, M., Das, A.M. and Das, D., eds, The Evolution of Policing, Boca Raton: CRC Press, pp. 317-331.

Jenks, D., Johnson, L. M., and Matthews, T. (2012) 'Examining police integrity: Categorizing corruption vignettes'. In International Police Executive Symposium, Geneva Centre for the Democratic Control of Armed Forces, Coginta-for Police Reforms and Community Safety.

Kakamwa, C. (2014) 'Uganda to Increase Size of Police Force', New Vision, 26 December. Kato, J. (2016), 'Police most corrupt institution - UBOS', Daily Monitor, 22 June, http://www.monitor.co.ug/News/National/Police-most-corrupt-institution-UBOS/6883343261630-3jq36az/index.html (accessed 12 February 2019).

Khisa, M. (2014), 'Challenges to Policy Implementation in Uganda: Reflections on Politics and the State', Ugandan Journal of Management and Public Policy Studies 8(1): 28-43.

Klockars, C.B., Kutnjak Ivković, S., Harver, W.E. and Haberfeld, M.R. (2000) The Measurement of Police Integrity, Research in Brief, NCJ 181465, Rockville: National Institute of Justice.

Klockars, C.B., Kutnjak Ivković, S. and Haberfeld, M.R. (2006) Enhancing Police Integrity, Dordrecht: Springer. 
Kucukuysal, B. (2008) Determinants of Turkish police officers' perception of integrity: Impact of organizational culture, $\mathrm{PhD}$ thesis, University of Central Florida, http://etd.fcla.edu/CF/CFE0002242/Kucukuysal_Bahadir_200807_PhD.pdf (accessed 12 February 2019).

Kuo, S.Y. (2018) 'Police misconduct in Taiwan: comparing perceptions of the police and electronic gaming service workers', Crime, Law and Social Change 69(5): 657-679.

Kutnjak Ivković, S. (2015) 'Studying Police Integrity', in Kutnjak Ivković, S. and Haberfeld, M.R., eds, Measuring Police Integrity Across the World: Studies from Established Democracies and Countries in Transition, New York: Springer, pp. 1-36.

Kutnjak Ivković, S., Cajner Mraović, I., and Borovec, K. (2016) 'An Empirical Test of the Influence of Society at Large on Police Integrity in a Centralized Police System', Policing: An International Journal of Police Strategies and Management 39(2): 302-318.

Kutnjak Ivković, S. and Haberfeld, M.R. (2015) 'A Comparative Perspective on Police Integrity', in Kutnjak Ivković, S. and Haberfeld, M.R., eds, Measuring Police Integrity Across the World: Studies from Established Democracies and Countries in Transition, New York: Springer, pp. 329-368.

Kutnjak Ivković, S., Haberfeld, M., Kang, W., Peacock, R. and Sauerman, A. (2016) 'A multi-country comparative study of the perceived police disciplinary environments.' Policing: An International Journal of Police Strategies \& Management 39(2): 338-353.

Kutnjak Ivković, S. and Khechumyan, A. (2014) 'Measuring police integrity among urban and rural police in Armenia: From local results to global implications', International Journal of Comparative and Applied Criminal Justice 38(1): 39-61.

Kutnjak Ivković, S. and O'Connor Shelley, T. (2010) 'The code of silence and disciplinary fairness', Policing: An International Journal of Police Strategies \& Management 33(3): 548574.

Kutnjak Ivković, S. and Sauerman, A. (2013) 'Curtailing the code of silence among the South African police', Policing: An International Journal of Police Strategies \& Management 36(1): 175-198.

Kutnjak Ivković, S. and Sauerman, A. (2015) 'Threading the thin blue line: Transition towards democratic policing and the integrity of the South African police service', Policing and Society 25(1): 25-52.

Lasthuizen, K., Huberts, L. and Heres, L. (2011), 'How to Measure Integrity Violations: Towards a Validated Typology of Unethical Behavior', Public Management Review 13(3): 383-408.

Lee, H., Lim, H., Moore, D.D. and Kim, J. (2013) 'How police organizational structure correlates with frontline officers' attitudes toward corruption: A multilevel model', Police Practice and Research, 14(5): 386-401. 
Long, M. A., Cross, J. E., Shelley, T. O. and Kutnjak Ivković, S. (2013) 'The Normative Order of Reporting Police Misconduct: Examining the Roles of Offense Seriousness, Legitimacy, and Fairness', Social Psychology Quarterly 76(3): 242-267.

Lumu, D. (2014) 'Uganda Police changes name', New Vision, Kampala, http://www.newvision.co.ug/news/654457-uganda-police-changes-name.html (accessed 12 Feburary 2019).

Marx, G.T. (2001) 'Police and democracy', in M. Amir and S. Einstein (eds), Policing, Security and Democracy: Theory and Practice, vol. 2, Huntsville: Office of International Criminal Justice, http://web.mit.edu/gtmarx/www/dempol.html (accessed 12 February 2019).

Mastrofski, S. D., Jonathan-Zamir, T., Moyal, S., an Willis, J. J. (2016) 'Predicting procedural justice in police-citizen encounters', Criminal Justice and Behavior 43(1): 119-139.

Miles-Johnson, T. and Pickering, S. (2018) 'Police recruits and perceptions of trust in diverse groups', Police Practice and Research 19(4): 311-328.

Miles-Johnson, T. (2016) 'Perceptions of group value: How Australian transgender people view policing', Policing and society 26(6): 605-626.

Ministry of Finance, Planning and Economic Development (2017) 'National Budget Framework Paper FY 2018/19-FY 2022/23', http://budget.go.ug/budget/content/nationalbudget-framework-paper-6 (accessed 12 February 2019).

Myhill, A. and Bradford, B. (2013) 'Overcoming cop culture? Organizational justice and police officers' attitudes toward the public', Policing: An International Journal of Police Strategies \& Management 36(2): 338-356.

Porter, L.E., Prenzler, T. and Hine, K. (2015) 'Police integrity in Australia', in Kutnjak Ivković, S. and Haberfeld, M.R. (eds) Measuring Police Integrity Across the World: Studies from Established Democracies and Countries in Transition, New York: Springer, pp. 67-96.

Reynolds, P.D. and Helfers, R.C. (2018) 'Differences in Perceptions of Organizational Fairness Based on Job Characteristics among Police Officers', American Journal of Criminal Justice 43(2): 371-388.

Tangri, R. and Mwenda, A. (2013) The Politics of Elite Corruption in Africa: Uganda in Comparative African Perspective, Routledge: London.

Transparency International (2018) Corruption Perceptions Index 2018, https://www.transparency.org/cpi2018 (accessed 12 February 2019).

Transparency International-Kenya (2013) The East African Bribery Index 2013, http://tikenya.org/wp-content/uploads/2017/06/the-east-african-bribery-index-2013.pdf (accessed 12 February 2019).

Uganda Police (2013) Annual Crime and Traffic/Road Safety Report, http://www.upf.go.ug/download/publications(2)/Annual_Crime_and_Traffic_Road_Safety_R eport_2013(2).pdf (accessed 12 February 2019). 
Uganda Police (2017) Annual Crime Report 2017, https://www.upf.go.ug/wpcontent/uploads/2018/07/ANNUAL-CRIME-REPORT-2017.pdf (accessed 12 February 2019).

Uganda Police (2015) Directorates, http://www.upf.go.ug/directorate (accessed 12 February 2019).

Uganda Police Force (2007) Strengthening Statistics for Development Planning. Sector Strategic Plan for Statistics (2006/07-2010/11), http://www.ubos.org/onlinefiles/uploads/ubos/pdf\%20documents/PNSD/UPF\%20SSPS.pdf (accessed 12 Feburary 2019).

Waddington, P.A.J., Adang, O., Baker, D., Birkbeck, C., Feltes, T., Gerardo Gabaldón, L., Paes Machado, E., and Stenning, P. (2009) 'Singing the same tune? International continuities and discontinuities in how police talk about using force', Crime, Law and Social Change 52(2): 111-138.

Wagner, N., Rieger, M., Bedi, A. and Hout, W. (2017) 'Gender and Policing Norms: Evidence from Survey Experiments among Police Officers in Uganda', Journal of African Economies 26(4): 492-525.

Wagner, N., Hout, W. and Namara, R. (2019) 'Improving Police Integrity in Uganda: Impact Assessment of the Police Accountability and Reform Project', unpublished manuscript.

Wambua, P.M. (2015) 'Police corruption in Africa undermines trust, but support for law enforcement remains strong', Afrobarometer Dispatch 56.

Wolfe, S.E. and Piquero, A.R. (2011) 'Organizational justice and police misconduct', Criminal Justice and Behavior 38(4): 332-353.

World Bank (2019) 'Data: Uganda', https://data.worldbank.org/country/uganda (accessed 12 February 2019).

Xinhua News Agency (2007) Ugandan Police Force Undergoes Massive Overhaul Ahead of Commonwealth Summit, 1 July, http://en.people.cn/200707/02/eng20070702_389277.html (accessed 12 February 2019). 


\section{Group 1: Code of conduct among the police officers}

Case 1: Police mechanic repairing supervisor's car in exchange for holidays

Case 2: Police officer driving drunk and having an accident goes unreported by colleague

\section{Group 2: Bribery}

Case 3: Acceptance of freely offered meals and small gifts while on duty

Case 4: Speeding not reported in exchange for a bribe

\section{Group 3: Theft}

Case 5: Officer taking money from a lost wallet

Case 6: Police officer stealing goods when investigating a burglary

\section{Group 4: Refusal to register complaints}

Case 7: Refusal to register a complaint and humiliation of the complainant

Case 8: Refusal to register a complaint and a one-week detention for the complainant for

\section{Group 5: Reported severe crimes against individuals not followed up upon}

Case 9: Police officer refusing to register mistreatment of wife

Case 10: Reported murder not being followed up on

\section{Group 6: Undue force used by the police}

Case 11: Foot patrol torturing a thief

Case 12: Brutal strike down of a demonstration 


\begin{tabular}{|c|c|c|}
\hline & Mean & Std. Dev. \\
\hline \multicolumn{3}{|l|}{ Panel A: Individual level background characteristics } \\
\hline Age & 41.785 & 9.426 \\
\hline Gender $($ Female $=1)$ & 0.228 & \\
\hline Marital status (Married=1) & 0.843 & \\
\hline Participant is the household head & 0.843 & \\
\hline Household size & 6.672 & 3.992 \\
\hline \multicolumn{3}{|l|}{ Education levels (Excluded category: Primary education) } \\
\hline Secondary & 0.455 & \\
\hline Advanced secondary & 0.268 & \\
\hline Higher & 0.248 & \\
\hline \multicolumn{3}{|l|}{ Income level (Excluded category: Income $<200,000 U G X)$} \\
\hline Income 200,000-300,000UGX & 0.115 & \\
\hline Income $300,000-500,000 \mathrm{UGX}$ & 0.603 & \\
\hline Income 500,000-700,000UGX & 0.140 & \\
\hline Income>700,000UGX & 0.095 & \\
\hline \# habitable rooms & 1.750 & 1.103 \\
\hline \# mobile phones owned & 1.337 & 0.578 \\
\hline Does sport & 0.525 & \\
\hline Member of a club/community organization & 0.482 & \\
\hline \multicolumn{3}{|l|}{ Panel B: Work related covariates } \\
\hline Number of years spent as police officer & 18.800 & 10.556 \\
\hline \multicolumn{3}{|l|}{ Police rank (Excluded category: Low rank) } \\
\hline High rank & 0.060 & \\
\hline Medium rank & 0.322 & \\
\hline \multicolumn{3}{|c|}{ Police section (Excluded category: Other sections and duties) } \\
\hline Traffic & 0.043 & \\
\hline Investigation & 0.262 & \\
\hline Intelligence & 0.063 & \\
\hline General duties & 0.463 & \\
\hline \# rooms of police station & 12.758 & 9.259 \\
\hline \# police cars at station & 1.522 & 1.508 \\
\hline \# police motorcycles at station & 6.762 & 12.557 \\
\hline \# police bicycles at station & 2.147 & 5.361 \\
\hline \multicolumn{3}{|l|}{ Panel C: District-level control variables } \\
\hline Population size $(\log )$ & 12.941 & 0.242 \\
\hline Population growth & 2.226 & 0.777 \\
\hline Poverty head count rate & 22.310 & 8.539 \\
\hline Gini index & 0.398 & 0.073 \\
\hline Share of the population belonging to the largest ethnicity & 73.980 & 14.454 \\
\hline Police officers per 100,000 inhabitants & 133.214 & 0.090 \\
\hline Crime rate & 338.232 & 143.510 \\
\hline Homicide rate & 8.629 & 3.910 \\
\hline
\end{tabular}

Note: The sample consists of 600 police officers. Descriptive statistics of district-level control variables are calculated on the basis of 10 district-level observations. 
Table 3: Descriptive statistics of the outcome variable

\begin{tabular}{lll}
\hline \hline & Mean & Std. Dev. \\
\cline { 2 - 3 } Own seriousness & 3.974 & 1.546 \\
Own reporting & 4.154 & 1.289 \\
Colleagues' seriousness & 3.878 & 1.423 \\
Disciplinary measure that should follow & 3.852 & 1.514 \\
Regarded as violation of official policy & 4.398 & 1.199 \\
\hline \hline
\end{tabular}

Note: The sample consists of 7,200 observations from 12 vignette cases responded to by 600 police officers. 
Table 4: Descriptive statistics of the perception variables

\begin{tabular}{|c|c|c|}
\hline & Mean & Std. Dev. \\
\hline \multicolumn{3}{|l|}{ Perception components } \\
\hline 1. Perceived crime in community & 2.540 & 1.236 \\
\hline 2. Similar treatment: Young vs. old & 4.038 & 1.095 \\
\hline 3. Similar treatment: Poor vs. rich & 3.565 & 1.296 \\
\hline 4. Similar treatment: Men vs. women & 3.808 & 1.203 \\
\hline 5. Confidence in own work & 4.582 & 0.835 \\
\hline 6. Confidence in work of colleagues & 4.428 & 0.889 \\
\hline 7. Police: Duty to always enforce the law & 4.715 & 0.701 \\
\hline $\begin{array}{l}\text { 8. Police treats people fairly and with } \\
\text { respect }\end{array}$ & 4.090 & 1.003 \\
\hline 9. Police manages crime well & 4.302 & 0.842 \\
\hline 10. Police is corrupt & 2.560 & 1.420 \\
\hline Average perception index & 3.863 & 0.459 \\
\hline PCA perception index & 0.000 & 1.820 \\
\hline
\end{tabular}

Note: All variables are Likert scaled on a scale from 1 to 5 with 1 representing the category "Definitely not", "Not very good" and "Much worse" and 5 representing the category "Definitely yes", "Very good" and "Much better". 
Table 5: Pair-wise correlations of the perception variables

\begin{tabular}{|c|c|c|c|c|c|c|c|c|c|c|}
\hline & $\begin{array}{l}\text { Perceived } \\
\text { crime in } \\
\text { community }\end{array}$ & $\begin{array}{l}\text { Similar } \\
\text { treatment: } \\
\text { Young-old }\end{array}$ & $\begin{array}{l}\text { Similar } \\
\text { treatment: } \\
\text { Poor-rich }\end{array}$ & $\begin{array}{l}\text { Similar } \\
\text { treatment: } \\
\text { Men- } \\
\text { women }\end{array}$ & $\begin{array}{l}\text { Confidence } \\
\text { in own } \\
\text { work }\end{array}$ & $\begin{array}{l}\text { Confidence } \\
\text { in work of } \\
\text { colleagues }\end{array}$ & $\begin{array}{l}\text { Police: Duty } \\
\text { to always } \\
\text { enforce the } \\
\text { law }\end{array}$ & $\begin{array}{l}\text { Police treat } \\
\text { people } \\
\text { fairly }\end{array}$ & $\begin{array}{l}\text { Police } \\
\text { manage } \\
\text { crime well }\end{array}$ & $\begin{array}{l}\text { Police are } \\
\text { corrupt }\end{array}$ \\
\hline $\begin{array}{l}\text { Perceived } \\
\text { crime in } \\
\text { community }\end{array}$ & 1 & & & & & & & & & \\
\hline $\begin{array}{l}\text { Similar } \\
\text { treatment: } \\
\text { Young-old }\end{array}$ & $-0.142 * * *$ & 1 & & & & & & & & \\
\hline $\begin{array}{l}\text { Similar } \\
\text { treatment: } \\
\text { Poor-rich }\end{array}$ & $-0.134 * * *$ & $0.463 * * *$ & 1 & & & & & & & \\
\hline $\begin{array}{l}\text { Similar } \\
\text { treatment: } \\
\text { Men-women }\end{array}$ & $-0.101 * *$ & $0.485^{* * *}$ & $0.467 * * *$ & 1 & & & & & & \\
\hline $\begin{array}{l}\text { Confidence } \\
\text { in own work }\end{array}$ & $-0.074 *$ & $0.226 * * *$ & $0.159 * * *$ & $0.186 * * *$ & 1 & & & & & \\
\hline $\begin{array}{l}\text { Confidence } \\
\text { in work of } \\
\text { colleagues }\end{array}$ & $-0.130 * * *$ & $0.259 * * *$ & $0.317 * * *$ & $0.305^{* * *}$ & $0.404 * * *$ & 1 & & & & \\
\hline $\begin{array}{l}\text { Police: Duty } \\
\text { to always } \\
\text { enforce law }\end{array}$ & $-0.010 * *$ & $0.140 * * *$ & $0.099 * *$ & $0.189 * * *$ & $0.170 * * *$ & $0.325 * * *$ & 1 & & & \\
\hline $\begin{array}{l}\text { Police treat } \\
\text { people fairly }\end{array}$ & $-0.129 * * *$ & $0.267 * * *$ & $0.455^{* * *}$ & $0.280 * * *$ & $0.119 * *$ & $0.301 * * *$ & $0.203 * * *$ & 1 & & \\
\hline $\begin{array}{l}\text { Police } \\
\text { manage } \\
\text { crime well }\end{array}$ & $-0.195 * * *$ & $0.259 * * *$ & $0.384 * * *$ & $0.258 * * *$ & $0.192 * * *$ & $0.358 * * *$ & $0.231 * * *$ & $0.571 * * *$ & 1 & \\
\hline $\begin{array}{l}\text { Police are } \\
\text { corrupt }\end{array}$ & $0.149 * * *$ & $-0.176 * * *$ & $-0.353 * * *$ & $-0.252 * * *$ & -0.049 & $-0.231 * * *$ & $-0.170 * * *$ & $-0.221 * * *$ & $-0.218 * * *$ & 1 \\
\hline
\end{tabular}

Note: Pair-wise correlations of the different components of the perception about the police. $* * * * * * *$ denotes statistical significance at a significance level of $1 / 5 / 10$ percent, respectively. 
Table 6: Results with detailed perception components

\begin{tabular}{|c|c|c|c|c|c|}
\hline & $\begin{array}{l}\text { Own } \\
\text { seriousness }\end{array}$ & $\begin{array}{l}\text { Own } \\
\text { reporting }\end{array}$ & $\begin{array}{l}\text { Colleagues' } \\
\text { seriousness }\end{array}$ & $\begin{array}{l}\text { Disciplinary } \\
\text { measure that } \\
\text { should follow }\end{array}$ & $\begin{array}{l}\text { Regarded as } \\
\text { violation of } \\
\text { official policy }\end{array}$ \\
\hline \multicolumn{6}{|l|}{ Perception components } \\
\hline \multirow[t]{2}{*}{ 1. Perceived crime in community } & 0.023 & -0.036 & -0.013 & -0.014 & -0.040 \\
\hline & $(0.034)$ & $(0.022)$ & $(0.030)$ & $(0.025)$ & $(0.029)$ \\
\hline 2. Similar treatment: Young vs. old & -0.069 & 0.043 & $-0.074 * *$ & 0.003 & 0.016 \\
\hline 3. Similar treatment: Poor vs. rich & $(0.044)$ & $(0.027)$ & $(0.037)$ & $(0.030)$ & $(0.026)$ \\
\hline \multirow[t]{2}{*}{ 4. Similar treatment: Men vs. women } & 0.054 & $0.124 * * *$ & $0.078 * *$ & -0.011 & -0.010 \\
\hline & $(0.041)$ & $(0.038)$ & $(0.037)$ & $(0.029)$ & $(0.026)$ \\
\hline \multirow[t]{2}{*}{ 5. Confidence in own work } & 0.085 & -0.002 & 0.042 & 0.027 & $0.088 * *$ \\
\hline & $(0.058)$ & $(0.036)$ & $(0.048)$ & $(0.039)$ & $(0.042)$ \\
\hline \multirow[t]{2}{*}{ 8. Police treats people fairly and with respect } & $0.150 * * *$ & 0.034 & $0.161 * * *$ & 0.061 & -0.054 \\
\hline & $(0.055)$ & $(0.022)$ & $(0.050)$ & $(0.040)$ & $(0.037)$ \\
\hline \multirow[t]{2}{*}{ 9. Police manages crime well } & -0.054 & 0.021 & -0.010 & -0.023 & 0.008 \\
\hline & $(0.058)$ & $(0.030)$ & $(0.052)$ & $(0.045)$ & $(0.043)$ \\
\hline \multirow[t]{2}{*}{ 10. Police is corrupt } & $0.071 * *$ & 0.031 & 0.006 & -0.012 & $0.064 * * *$ \\
\hline & $(0.031)$ & $(0.040)$ & $(0.027)$ & $(0.023)$ & $(0.025)$ \\
\hline
\end{tabular}

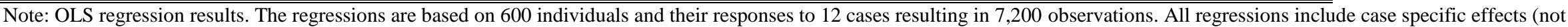
shown). Individual level socio-economic characteristics that are controlled for but coefficients are not shown: age, gender, marital status, whether the respondent is household head, education level (dummies for secondary, advanced secondary and higher education, excluded category: primary education), household size, income level (dummies), number of habitable rooms in the house, number of mobile phones owned, whether the person does sports and whether the person is a member of a community organization. Work related characteristics that are controlled for but coefficients are not shown: Years of service, rank (high rank and medium rank, low rank forms the excluded category), number of rooms of the police station, number of police cars, number of police motorcycles, number of police bicycles, Police section (traffic, investigation, intelligence, general duties, excluded category: Other sections and duties). District-level characteristics that are controlled for but coefficients are not shown: Population size (log), population growth, rate of police officers, crime rate, homicide rate, poverty head count, Gini coefficient, share of the population belonging to the main ethnicity of the district. Standard errors are clustered at the level of the individual respondent. 
Table 7: Results employing a perception index

\begin{tabular}{|c|c|c|c|c|c|c|c|c|c|c|}
\hline \multirow{4}{*}{$\begin{array}{l}\text { Average perception } \\
\text { index }\end{array}$} & \multicolumn{2}{|c|}{ Own seriousness } & \multicolumn{2}{|c|}{ Own reporting } & \multicolumn{2}{|c|}{$\begin{array}{l}\text { Colleagues' } \\
\text { seriousness }\end{array}$} & \multicolumn{2}{|c|}{$\begin{array}{l}\text { Disciplinary measure } \\
\text { that should follow }\end{array}$} & \multicolumn{2}{|c|}{$\begin{array}{l}\text { Regarded as violation } \\
\text { of official policy }\end{array}$} \\
\hline & Average & PCA & Average & PCA & Average & PCA & Average & PCA & Average & PCA \\
\hline & $0.203 * *$ & & $0.378 * * *$ & & $0.371 * * *$ & & 0.088 & & $0.144 *$ & \\
\hline & $(0.091)$ & & $(0.065)$ & & $(0.079)$ & & $(0.062)$ & & $(0.087)$ & \\
\hline PCA perception index & & $\begin{array}{l}0.023 \\
(0.023)\end{array}$ & & $\begin{array}{l}0.098 * * * \\
(0.016)\end{array}$ & & $\begin{array}{l}0.104 * * * \\
(0.020)\end{array}$ & & $\begin{array}{l}0.031 * * \\
(0.016)\end{array}$ & & $\begin{array}{l}0.026 \\
(0.021)\end{array}$ \\
\hline
\end{tabular}

Note: Compare note to table 6 for detailed information about the employed empirical specifications. 
Appendix 1. Supplementary tables

Table A1: Detailed descriptive statistics of the vignette cases

\begin{tabular}{|c|c|c|c|c|c|}
\hline & Own seriousness & Own reporting & $\begin{array}{l}\text { Colleagues' } \\
\text { seriousness }\end{array}$ & $\begin{array}{l}\text { Disciplinary measure that } \\
\text { should follow }\end{array}$ & $\begin{array}{c}\text { Regarded as violation of } \\
\text { official policy }\end{array}$ \\
\hline \multicolumn{6}{|c|}{ Group 1: Code of conduct among the police officers } \\
\hline \multicolumn{6}{|c|}{ Case 1: Police mechanic repairing supervisor's car in exchange for holidays } \\
\hline Mean & 3.720 & 4.058 & 3.693 & 3.803 & 4.243 \\
\hline Std. Dev. & 1.566 & 1.305 & 1.422 & 1.348 & 1.303 \\
\hline \multicolumn{6}{|c|}{ Case 2: Police officer driving drunk and having an accident goes unreported by colleague } \\
\hline Overall mean & 3.710 & 3.918 & 3.597 & 3.645 & 4.107 \\
\hline Std. Dev. & 1.585 & 1.397 & 1.463 & 1.459 & 1.371 \\
\hline \multicolumn{6}{|c|}{ Group 2: Bribery } \\
\hline \multicolumn{6}{|c|}{ Case 3: Acceptance of freely offered meals and small gifts while on duty } \\
\hline Overall mean & 3.533 & 3.165 & 3.445 & 3.150 & 3.955 \\
\hline Std. Dev. & 1.534 & 1.552 & 1.500 & 1.399 & 1.488 \\
\hline \multicolumn{6}{|c|}{ Case 4: Speeding not reported in exchange for a bribe } \\
\hline Mean & 4.367 & 4.253 & 3.920 & 4.313 & 4.542 \\
\hline Std. Dev. & 1.279 & 1.164 & 1.424 & 1.263 & 1.093 \\
\hline \multicolumn{6}{|c|}{ Group 3: Theft } \\
\hline \multicolumn{6}{|c|}{ Case 5: Officer taking money from a lost wallet } \\
\hline Mean & 4.042 & 4.272 & 3.795 & 4.110 & 4.433 \\
\hline Std. Dev. & 1.537 & 1.248 & 1.454 & 1.428 & 1.154 \\
\hline \multicolumn{6}{|c|}{ Case 6: Police officer stealing goods when investigating a burglary } \\
\hline Mean & 4.472 & 4.603 & 4.327 & 5.068 & 4.643 \\
\hline Std. Dev. & 1.228 & 0.913 & 1.188 & 1.205 & 0.965 \\
\hline
\end{tabular}

Table A1: Cont.

$\begin{array}{ccll}\text { Own seriousness } & \text { Own reporting } & \begin{array}{l}\text { Colleagues' } \\ \text { seriousness }\end{array} & \begin{array}{l}\text { Disciplinary measure that Regarded as violation of } \\ \text { should follow }\end{array} \\ \text { Group 4: } \text { Refusal to register complaints } & & \text { official policy }\end{array}$


Mean

$3.622 \quad 4.033$

3.542

3.478

4.313

Std. Dev.

1.232

1.476

1.300

Case 8: Refusal to register a complaint and a one-week detention for the complainant for false accusation
Mean
4.010
4.473
3.970
4.122
4.563
Std. Dev.
1.593
1.043
1.424
1.239
1.059

Group 5: Reported severe crimes against individuals not followed up upon

Case 9: Police officer refusing to register mistreatment of wife
Mean
4.275
4.472
4.125
4.012
4.592

Std. Dev.

1.020

1.284

1.280

0.976

ase 10: Reported murder not being followed up on

$$
3.922 \quad 4.467
$$

4.100

2.728

4.530

Std. Dev.

0.997

1.324

1.204

1.059

he police

\begin{tabular}{|c|c|c|c|}
\hline Mean & 3.895 & 4.077 & 3.783 \\
\hline Std. Dev. & 1.565 & 1.303 & 1.427 \\
\hline
\end{tabular}

Case 11: Foot patrol torturing a thief

Case 12: Brutal strike down of a demonstration

\begin{tabular}{llllll} 
Mean & 4.117 & 4.053 & 4.235 & 3.923 & 4.508 \\
Std. Dev. & 1.578 & 1.490 & 1.354 & 2.125 & 1.147 \\
\hline
\end{tabular}

Note: The number of observations per case and response is 600 . 
Table A2: Results with detailed perception components

\begin{tabular}{lccccc}
\hline \hline & $\begin{array}{c}\text { Own } \\
\text { seriousness }\end{array}$ & $\begin{array}{c}\text { Own } \\
\text { reporting }\end{array}$ & $\begin{array}{c}\text { Colleagues' } \\
\text { seriousness }\end{array}$ & $\begin{array}{c}\text { Disciplinary } \\
\text { measure that } \\
\text { should follow }\end{array}$ & $\begin{array}{c}\text { Regarded as } \\
\text { violation of } \\
\text { official policy }\end{array}$ \\
\hline Perception components & 0.024 & -0.036 & -0.013 & -0.015 & -0.040 \\
1. Perceived crime in community & $(0.034)$ & $(0.022)$ & $(0.030)$ & $(0.025)$ & $(0.029)$ \\
& -0.067 & 0.045 & $-0.077 * *$ & -0.001 & 0.020 \\
2. Similar treatment: Young vs. old & $(0.046)$ & $(0.032)$ & $(0.037)$ & $(0.031)$ & $(0.026)$ \\
& -0.012 & 0.031 & 0.056 & -0.003 & -0.014 \\
3. Similar treatment: Poor vs. rich & $(0.044)$ & $(0.027)$ & $(0.037)$ & $(0.029)$ & $(0.025)$ \\
& 0.056 & $0.122^{* * *}$ & $0.076 * *$ & -0.014 & -0.006 \\
4. Similar treatment: Men vs. women & $(0.041)$ & $(0.039)$ & $(0.037)$ & $(0.029)$ & $(0.026)$ \\
& 0.082 & -0.004 & 0.045 & 0.031 & $0.084^{* *}$ \\
5. Confidence in own work & $(0.057)$ & $(0.037)$ & $(0.049)$ & $(0.039)$ & $(0.041)$ \\
& 0.003 & $0.093 *$ & -0.013 & 0.025 & $0.065^{*}$ \\
6. Confidence in work of colleagues & $(0.057)$ & $(0.053)$ & $(0.046)$ & $(0.041)$ & $(0.036)$ \\
& 0.046 & 0.038 & 0.071 & 0.015 & $0.157^{* * *}$ \\
7. Police: Duty to always enforce the law & $(0.062)$ & $(0.035)$ & $(0.060)$ & $(0.055)$ & $(0.054)$ \\
& $0.149 * * *$ & 0.035 & $0.162^{* * *}$ & 0.062 & -0.055 \\
8. Police treat people fairly and with respect & $(0.055)$ & $(0.022)$ & $(0.050)$ & $(0.040)$ & $(0.036)$ \\
9. Police manage crime well & -0.058 & 0.023 & -0.006 & -0.017 & 0.002 \\
& $(0.058)$ & $(0.030)$ & $(0.052)$ & $(0.045)$ & $(0.043)$ \\
10. Police are corrupt & $0.072^{* *}$ & 0.028 & 0.004 & -0.015 & $0.067^{* * *}$ \\
& $(0.031)$ & $(0.041)$ & $(0.027)$ & $(0.023)$ & $(0.024)$ \\
\hline \hline
\end{tabular}

Note: The regressions are based on 600 individuals and their responses to 12 cases resulting in 7,200 observations. All regressions include case specific and district specific effects (not shown). Individual level socio-economic characteristics that are controlled for but coefficients are not shown: age, gender, marital status, whether the respondent is household head, education level (dummies for secondary, advanced secondary and higher education, excluded category: primary education), household size, income level (dummies), number of habitable rooms in the house, number of mobile phones owned, whether the person does sports and whether the person is a member of a community organization. Work related characteristics that are controlled for but coefficients are not shown: Years of service, rank (high rank and medium rank, low rank forms the excluded category), number of rooms of the police station, number of police cars, number of police motorcycles, number of police bicycles, Police section (traffic, investigation, intelligence, general duties, excluded category: Other sections and duties). Standard errors are clustered at the level of the individual respondent. 
Table A3: Results employing a perception index

\begin{tabular}{|c|c|c|c|c|c|c|c|c|c|c|}
\hline \multirow[b]{3}{*}{ Average perception index } & \multicolumn{2}{|c|}{ Own seriousness } & \multicolumn{2}{|c|}{ Own reporting } & \multicolumn{2}{|c|}{$\begin{array}{l}\text { Colleagues' } \\
\text { seriousness }\end{array}$} & \multicolumn{2}{|c|}{$\begin{array}{l}\text { Disciplinary measure } \\
\text { that should follow }\end{array}$} & \multicolumn{2}{|c|}{$\begin{array}{l}\text { Regarded as violation } \\
\text { of official policy }\end{array}$} \\
\hline & Average & PCA & Average & PCA & Average & PCA & Average & PCA & Average & PCA \\
\hline & $\begin{array}{l}0.202 * * \\
(0.090)\end{array}$ & & $\begin{array}{c}0.377 * * * \\
(0.065)\end{array}$ & & $\begin{array}{c}0.373 * * * \\
(0.079)\end{array}$ & & $\begin{array}{c}0.091 \\
(0.062)\end{array}$ & & $\begin{array}{c}0.141 \\
(0.086)\end{array}$ & \\
\hline PCA perception index & & $\begin{array}{c}0.021 \\
(0.023)\end{array}$ & & $\begin{array}{c}0.097 * * * \\
(0.016)\end{array}$ & & $\begin{array}{c}0.106 * * * \\
(0.020)\end{array}$ & & $\begin{array}{c}0.033 * * \\
(0.016)\end{array}$ & & $\begin{array}{c}0.024 \\
(0.021)\end{array}$ \\
\hline
\end{tabular}

Note: Compare note to table 5 for detailed information about the employed empirical specifications. 


\section{Appendix 2. The 12 vignette cases}

\section{Group 1: Code of conduct among the police officers}

Case 1: A police officer, who happens to be a very good auto mechanic, is scheduled to work during coming holidays. The supervisor offers to give him these days off, if he agrees to repair her/his personal car. Evaluate the supervisor's behavior.

Case 2: At 2:00 a.m., a police officer, who is on duty, is driving her/his patrol car on a deserted road. S/he sees a vehicle that has been driven off the road and is stuck in a ditch. $\mathrm{S} / \mathrm{he}$ approaches the vehicle and observes that the driver is not hurt but is obviously drunk. $\mathrm{S} /$ he also finds that the driver is a police officer. $\mathrm{S} /$ he transports the driver home. Evaluate the behavior of the police officer on duty.

\section{Group 2: Bribery}

Case 3: A police officer routinely accepts free meals, cigarettes, and other items of small value from merchants on his duty. S/he does not solicit these gifts and is careful not to abuse the generosity of those who give gifts to her/him.

Case 4: A police officer stops a motorist for speeding. The officer agrees to accept a personal gift of half of the amount of the fine in exchange for not taking the offending motorist to court to answer to charges for the traffic offence.

\section{Group 3: Theft}

Case 5: A police officer finds a wallet in a parking lot. It contains an amount of money equivalent to a full day's pay for that officer. S/he reports the wallet as lost property but keeps the money for her/himself.

Case 6: A police officer discovers a burglary of a general merchandise shop. The display cases are smashed, and it is obvious that many items have been taken. While searching the shop, s/he takes 10 jerricans of cooking oil and 1 sack of posho of 100 kilograms worth about a month's pay for that officer. S/he reports that the items had been stolen during the burglary.

\section{Group 4: Refusal to register complaints}

Case 7: A formerly arrested man comes to the police station and wants to fill in a complaint form. He claims that he was not treated properly during his arrest. The police officer who is in charge laughs at him and sends him away.

Case 8: A men goes to a police station to register a complaint over one of their officers who had beaten and tortured him. At the station he finds a friend of the officer who tortured him. The friend refuses to register his complaint and instead decides to detain him for a weak over giving false information to the police. Evaluate the behavior of the friend. 


\section{Group 5: Reported severe crimes against individuals not followed up upon}

Case 9: A women goes to the police station to report a case where her husband has been beating her for the last one year. She lost one of her teeth and has a damaged eye due to the beating. The police officer on duty thinks this is a mere family dispute and not a crime for the police to handle. S/he refuses to register the case.

Case 10: A police officer on duty receives a woman who wants to register a case of murder of her child by a neighbor. The officer registers the case and promises to follow up and arrest the suspect in a few hours' time. Two days down the road, the suspect has not been arrested and was sending messages threatening to harm the complainant. The woman went back to the same police station to report the scenario and the suspect was arrested and detained at the police station. However, the suspect was released immediately on account that there was not enough evidence to convict him. Evaluate the behavior of the police officer who first received the woman.

\section{Group 6: Undue force used by the police}

Case 11: Two police officers on foot patrol surprise a man who is attempting to break into a shop. The man flees. They chase him for about $1 \frac{1}{2}$ a kilometer before apprehending him by tackling him and wrestling him to the ground. After he is under control, both officers punch him a couple of times in the stomach and step on his back several times as punishment for fleeing and resisting.

Case 12: A sub-district has a challenge of water shortage for a period of four months. The area leader together with residents decide to petition national water for the poor services and failure to deliver. However, the situation continues for two more months. The area leader and the residents opt to stage a peaceful demonstration as a way of showing their dissatisfaction. No sooner had the demonstration started than the District Police Commander deployed a team of officers with teargas and firing of live ammunitions killing 20 of the demonstrators including the area leader. Evaluate the District Police Commander's behavior. 